\title{
CHALLENGES IN SMALL-SCALE COMBUSTION OF AGRICULTURAL BIOMASS FUELS
}

\author{
L. Carvalho ${ }^{(1,2)}$, J. Lundgren ${ }^{(2)}$, E. Wopienka ${ }^{(1)}$, M. Öhman ${ }^{(2)}$ \\ (I) Austrian Bioenergy Centre, Rottenhauserstrasse. 1, 3250 Wieselburg, Austria \\ ${ }^{(2)}$ Division of Energy Engineering, Luleå University of Technology, 97184 Luleå, Sweden
}

\begin{abstract}
In the present work, several agricultural biomass fuels, namely straw, Miscanthus, maize whole crop and horse manure mixed with two bedding materials, wood shavings and straw, were reviewed in terms of fuel characteristics. Furthermore, these fuels were tested in several existing boiler technologies and the particulate and gaseous emissions were monitored. The ash was analysed visually in terms of presence of sintered material. As expected, all the fuels showed problems with ash lumping and slag formation, especially straw and horse manure. Different boiler technologies showed different operational performance regarding ash and slag management. Miscanthus was the best fuel tested regarding emissions. Maize and horse manure are problematic fuels regarding $\mathrm{NO}_{\mathrm{x}}$ and particulate emissions. Due to the big variation of the fuel properties and therefore combustion behaviour of agricultural biomass, further R\&D is required to adapt the existing small-scale combustion systems for these new fuels. Improvements in the combustion chamber design, controlling technology and ash removal systems of small-scale combustion systems are therefore essential.
\end{abstract}

Keywords Agricultural fuels, combustion, emissions, ash, slagging

\section{INTRODUCTION}

Currently, the share of renewable energy in the European Union (EU) is slightly above $6 \%$ and according to the European Commission's white paper, the goal is to double this value by the year 2010 []. Biomass accounts for about half of the renewable energy used in the EU [] and there is large potential to further increase the utilisation. Therefore, biomass is expected to play an important rule in reaching the European Commission's target. In particular, the share of solid biomass for heating purposes can be further increased by replacing oil and gas fired furnaces with biomass boilers and by expanding the spectrum of biomass raw materials for small-scale combustion systems, e.g., agricultural residues and energy crops. Furthermore, the interest in using alternative biomass materials for smallscale combustion systems has been increasing in several European countries 
due to an increase of demand and competition for wooden materials. The reasons for this trend are mainly of economic nature, such as:

- The increasing demand and sale of small-scale pellet boilers in several European countries, e.g., Austria and Germany, which have led to an increased demand of fuel supply, i.e., woody materials;

- The growing demand for woody biomass in other sectors, such as transportation, sawmills and pulp and paper industry.

There are several benefits from growing energy plants or use agricultural residues for energy purposes. Energy crops can provide a supplemental income for farmers and at the same time prevent soil erosion. Furthermore, the utilisation of a broader variety of biomass materials can create more job opportunities for power- and agricultural equipment industries. Straw is an agricultural residue that typically is used as bedding material for cattle or left on the fields as soil fertilizers. However, in places with dry climate, the full grown straw may not be suitable as fertiliser and could instead be valorised as biomass fuel. Another interesting new and alternative residue that can be used as a fuel for energy purposes is horse manure mixed with different bedding materials like straw and woodshavings. As one measure to reduce the ever-increasing amount of refuse at landfills, the European Commission has decided to prohibit deposition of organic materials in Europe. Due to this, stable owners need to find practical, environmental and economic alternatives for handling the horse manure. One possibility is composting and further use as fertiliser. However, according to [], this possibility is only economically viable if the land is sufficiently near the manure production to minimise transportation costs. On the other hand, horse manure may contain oat weeds and cereal farmers normally hesitate to accept this type of fertiliser on their fields. Consequently, the combustion of horse manure for heat generation is an attractive solution for stable owners and riding schools.

Despite the high availability, rapid growth, abundance or underutilisation, agricultural residues and energy crops have, in general, certain physical and chemical properties that may induce problems during combustion. In addition to their relatively low heating value, on average $5 \%$ to $10 \%$ lower than wood, they have higher ash content, lower ash melting points and higher concentrations of nitrogen $(\mathrm{N})$, sulphur $(\mathrm{S})$ and chlorine (Cl) than typical woody fuels []. Large ash quantities in connection with low ash melting points can cause disturbances by the formation of deposits in combustion systems not prepared for non-wood fuels. The sintered deposits or slags are either glassy fused coatings or agglomerates of ash bonded together with a glassy material []. The alkali (sum of potassium and sodium oxides), alkali earths (sum of magnesium and calcium oxides) and silica $\left(\mathrm{SiO}_{2}\right)$ are very important ash components in the formation of slag. 
Silica is often a major element in ash rich fuels and does not constitute a problem for biomass boilers itself due to the high melting point $\left(=1713^{\circ} \mathrm{C}\right)$. However, Silicon $(\mathrm{Si})$ in combination with potassium $(\mathrm{K})$ can lead to formation of low melting points compounds which may slag at normal boiler furnace temperatures $\left(800^{\circ} \mathrm{C}\right.$ to $\left.900^{\circ} \mathrm{C}\right)$ [, ]. Calcium $(\mathrm{Ca})$ and magnesium $(\mathrm{Mg})$ normally increase the melting temperature of ashes []. Results from chemical characterization of slag samples show that they consist of a large number of different particles held together by a "sticky" silicate melt []. High concentrations of sulphur, nitrogen and chlorine intensify the emissions of sulphur dioxide $\left(\mathrm{SO}_{2}\right)$, nitrogen oxides $\left(\mathrm{NO}_{\mathrm{x}}\right)$, hydrogen chloride $(\mathrm{HCl})$ and may cause the formation of dioxins and furans under unfavourable combustion conditions []. According to [, ], the guiding ranges for nitrogen, sulphur and chlorine in biomass fuels (in weight percent of dry fuel) for unproblematic thermal utilisation are:

- $\mathrm{N}$ concentration below $0.6 \%$ for $\mathrm{NO}_{\mathrm{x}}$ emissions

- $\mathrm{Cl}$ concentration below $0.1 \%$ for $\mathrm{HCl}$ emissions and $0.3 \%$ for dioxins and furans emissions

- $\mathrm{S}$ concentrations below $0.2 \%$ for $\mathrm{SO}_{\mathrm{x}}$ emissions

Chlorine and sulphur are, besides promoting the formation of deposits, also involved in corrosion reactions of metals $[,$,$] . Furthermore, combustion of$ any type of biomass fuels also involves emission of particles from inorganic materials and particles due to an incomplete combustion process. The inorganic material is a result of entrainment of ash particles and salts, basically consisting of $\mathrm{K}, \mathrm{Na}, \mathrm{S}, \mathrm{Cl}$ and $\mathrm{Zn}$ [] in the flue gas. Particle emissions from incomplete combustion include soot, char and condensable organic particles (tar) [, ]. The emission of the latter type of particles, as for $\mathrm{CO}$ emissions, may be a result of too low combustion temperatures, too short residence time or lack of available oxygen [].

Over the years, small-scale biomass combustion systems have reached a high quality performance level. The efficiency has increased, the emissions have decreased, fully automatic operation systems have been developed and the combustion technology has been optimised for woody biomass fuels. The future utilisation of a wider base of raw materials for thermal conversion in small-scale combustion systems requires further research and development of the existing boiler technologies. The challenge is to adapt and develop these systems enabling a trouble free operation with low emissions also when burning non-woody and lower quality biomass fuels.

The increasing interest in alternative biomass materials in Austria has led to the creation of threshold values for the combustion of non-woody biomass fuels in small-scale combustion systems with nominal heat output up to $400 \mathrm{~kW}$. This new regulation ("Art. 15a B-VG Schutzmaßnahmen betreffend Kleinfeuerungsanlagen") [] will come into force in all federal 
states of Austria in the near future. This directive specifies emission limits for non-wood standardised fuels for carbon monoxide (CO), nitrogen oxides $\left(\mathrm{NO}_{\mathrm{x}}\right)$, organically bound carbon (OGC) and total suspended particles (TSP). The new regulation also defines stricter limits for OGC and TSP for wood combustion than the present directive. At present, no official regulations for small- and medium scale biomass combustion plants concerning emissions of $\mathrm{CO}, \mathrm{NO}_{\mathrm{x}}$ or TSP exist in Sweden, but there are recommended limits. In Sweden, there is no emission limits for small-scale systems appliances up to a nominal heat output of $500 \mathrm{~kW}$, but only guideline emission levels for CO and TSP that is recommended to be followed. Table 1 shows the future limits in Austria and the recommended emission values in Sweden respectively.

Table 1. Emission limits for standardised fuels in Austria (for automatically fed boilers up to a nominal heat output of $400 \mathrm{~kW}$, according to []) and recommended emission values in Sweden (for small-scale combustion appliances up to a nominal heat power output of $500 \mathrm{~kW}$, according to []).

\begin{tabular}{|c|c|c|c|c|c|}
\hline Region & Fuel & CO & NO $_{\mathbf{x}}$ & OGC & TSP \\
\hline \multirow{2}{*}{ Austria } & Wood & $500 *$ & $150 *$ & $30 *$ & $50 *$ \\
\cline { 2 - 6 } & Non-wood & $500 *$ & $300 *$ & $30 *$ & $60 *$ \\
\hline Sweden & Wood & $500 * *$ & - & - & $350 * *$ \\
\hline
\end{tabular}

* Value in $\mathrm{mg} / \mathrm{MJ}, * *$ Value in $\mathrm{mg} / \mathrm{Nm}^{3}$ at $11 \% \mathrm{O}_{2}$.

The main objective of this study has been to review the fuel characteristics of a variety of agricultural raw materials such as straw, Miscanthus, maize and horse manure mixed with two different bedding materials, wood shavings and straw. Furthermore, the fuels that may cause technical and environmental problems were identified. Combustion tests were carried out with the different fuels and the gaseous and particulate emissions were surveyed. Different boiler technologies with thermal outputs in the range of 10 to $350 \mathrm{~kW}_{\text {th }}$ were tested and their combustion performance for handling non-woody biomass fuels was analysed.

\section{EXPERIMENTAL}

\section{Combustion systems and fuels}

The combustion tests were carried out in biomass boilers available on the market. The boilers had originally been developed and optimised for woody biomass fuels. Table 2 gives an overview of the boiler characteristics relevant for this paper. A more detailed description of Boilers S1 and S2 can be found in [,]. 
Table 2. Relevant characteristics of the pellet boilers used in the combustion tests.

\begin{tabular}{|c|c|c|c|c|}
\hline Boiler & $\begin{array}{c}\text { Nominal heat } \\
\text { output [kW] }\end{array}$ & Fuel Supply & $\begin{array}{c}\text { Control } \\
\text { principle }\end{array}$ & Ash discharge \\
\hline Boiler A1 & 15 & Under feed & $\begin{array}{l}\text { Flue gas } \\
\text { temperature }\end{array}$ & $\begin{array}{c}\text { Continuously ash dropping } \\
\text { over the grate edge } *\end{array}$ \\
\hline Boiler A2 & 25 & Under feed & Lambda & $\begin{array}{c}\text { Continuously ash dropping } \\
\text { over the grate edge * }\end{array}$ \\
\hline Boiler A3 & 10 & Top feed & $\begin{array}{l}\text { Open loop } \\
\text { control }\end{array}$ & Continuously though the grate \\
\hline Boiler A4 & 15 & Horizontal feed & Lambda & $\begin{array}{c}\text { Moving grate (horizontal } \\
\text { movements in predefined } \\
\text { intervals) * }\end{array}$ \\
\hline Boiler S1 & 350 & Horizontal feed & Lambda & $\begin{array}{c}\text { Continuously ash dropping } \\
\text { over the grate edge * }\end{array}$ \\
\hline Boiler S2 & 150 & Horizontal feed & Lambda & $\begin{array}{c}\text { Continuously ash dropping } \\
\text { over the grate edge * }\end{array}$ \\
\hline
\end{tabular}

* The ash was then carried automatically via a screw conveyor to the ash box.

Straw, Miscanthus and maize (whole crop), harvested in different years, were pelletised and burned in the different pellet boilers (see Table 3 ). Regarding the horse manure fuels, the share of bedding material (straw or wood-shavings) varies significantly from time to time depending on how careful the horse owners are when they clean the horseboxes. Normally, the share of bedding material is considerably higher than the share of manure, in the order of $90 / 10 \%$.

Table 3. Fuels used in the combustion tests.

\begin{tabular}{|c|c|c|c|c|c|c|}
\hline Fuel & $\begin{array}{l}\bar{z} \\
\stackrel{0}{0} \\
\stackrel{0}{0}\end{array}$ & 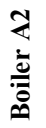 & 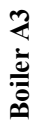 & 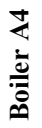 & 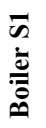 & బี \\
\hline Wood pellets & $\mathrm{x}$ & $\mathrm{x}$ & $\mathrm{x}$ & $\mathrm{x}$ & & \\
\hline Straw pellets (harvested in 2004) & $\mathrm{x}$ & $\mathrm{x}$ & $\mathrm{x}$ & & & \\
\hline Miscanthus pellets (harvested in 2004) & & $\mathrm{x}$ & $\mathrm{x}$ & & & \\
\hline Maize pellets - whole crop (harvested in 2004) & $\mathrm{x}$ & $\mathrm{x}$ & $\mathrm{x}$ & & & \\
\hline Straw pellets (harvested in 205 ) & & & $\mathrm{x}$ & $\mathrm{x}$ & & \\
\hline Miscanthus pellets (harvested in 2005) & $\mathrm{x}$ & & $\mathrm{x}$ & $\mathrm{x}$ & & \\
\hline Maize pellets - whole crop (harvested in 2005) & $\mathrm{x}$ & & $\mathrm{x}$ & $\mathrm{x}$ & & \\
\hline Horse manure with wood shavings & & & & & $\mathrm{x}$ & $\mathrm{x}$ \\
\hline Horse manure with straw & & & & & $\mathrm{x}$ & \\
\hline
\end{tabular}

\section{Combustion tests}

The combustion tests were performed partly in Austria and partly in Sweden.

The combustion tests preformed in Austria were carried out at the Austrian Bioenergy Centre (ABC) laboratory in Wieselburg and at test 
stands of project partners. The tests were carried out at full load over a period of 4 to 24 hours. The gaseous emissions as well as other relevant parameters, e.g., temperatures in the combustion chamber, flue gas temperature and total mass of the system, were measured continuously. NDIR (Non Dispersive Infra Red) instruments were used for NO, CO and $\mathrm{CO}_{2}$. For $\mathrm{O}_{2}$ and $\mathrm{NO}_{2}$ measurements, a paramagnetic cell instrument and an ultraviolet cell were used. With the exception of boiler A4, all pellet boilers were operated with the settings used for burning standard wood fuels. In boiler A4, which is equipped with a moving grate, the grate cleaning intervals were shortened to more effectively remove the ash from the primary combustion area. A second set of experiments with Boiler A2 were made after substituting the burner plate by a smaller one. Total dust emissions were measured for the combustion tests performed in boilers A3 and A4.

In Sweden, experiments with horse manure mixed with different bedding materials as fuels have been carried out partly in a test laboratory in Boden (Boiler S1) and partly in a demonstration plant in Timrå (Boiler S2). The former has a thermal output in the range of 150-350 kW while Boiler $\mathrm{S} 2$ operates in the range 50-150 kW. NDIR instruments were used for $\mathrm{NO}_{\mathrm{x}}$, $\mathrm{CO}$ and $\mathrm{CO}_{2}$. For $\mathrm{O}_{2}$ measurements, a paramagnetic cell instrument was used. Measurements of dust emissions were carried out in Boiler S2 during five different combustion experiments.

\section{RESULTS AND DISCUSSION}

\section{Fuel characteristics}

Table 4 shows the lower heating values (LHV), ash softening temperatures and the composition of the main and trace elements in the fuels tested. Even though the straw, Miscanthus and maize whole crop raw materials show some variations between the two years, for simplicity, only the fuel properties of the materials harvested in 2005 are shown.

Based on the composition of the different fuels, high $\mathrm{NO}_{\mathrm{x}}$ emissions are expected during straw, maize and horse manure combustion, since they have more than three times higher nitrogen content than wood fuels. The two horse manure mixtures and the straw pellets have a concentration of $\mathrm{Cl}$, which might cause problems with corrosion and $\mathrm{HCl}$ emissions. All the agricultural fuels show lower softening temperatures (horse manure fuels not analysed), higher ash contents and higher concentrations of $\mathrm{Si}$ and $\mathrm{K}$ than wood. Consequently, problems with ash sintering could be expected 
especially for straw pellets and horse manure and to a smaller extent for Miscanthus and maize.

Table 4. Fuel properties of the biomass fuels tested.

\begin{tabular}{|c|c|c|c|c|c|c|}
\hline Fuels & $\begin{array}{c}\text { Wood } \\
\text { pellets }\end{array}$ & $\begin{array}{c}\text { Straw } \\
\text { pellets }\end{array}$ & $\begin{array}{c}\text { Miscanthus } \\
\text { pellets }\end{array}$ & $\begin{array}{c}\text { Maize } \\
\text { pellets }\end{array}$ & $\begin{array}{c}\text { Horse } \\
\text { manure } \\
\text { + wood }\end{array}$ & $\begin{array}{c}\text { Horse } \\
\text { manure } \\
\text { + Straw }\end{array}$ \\
\hline LHV [mg/MJ] dry fuel & 18.8 & 17.3 & 17.8 & 17.5 & 18,1 & 16.3 \\
\hline Softening Temperature $\left[{ }^{\circ} \mathrm{C}\right]$ & $>1100$ & 800 & 1010 & 910 & - & - \\
\hline Moisture content [\%] & 9.4 & 7.9 & 8.7 & 11.7 & 57 & 59 \\
\hline Fuel Composition [\% $]_{\text {dry fuel }}$ \\
\hline Ash & 0.2 & 5.7 & 3.3 & 3.4 & 7.3 & 14.7 \\
\hline $\mathrm{C}$ & 50.7 & 47.3 & 47.3 & 45.9 & 48.6 & 43.6 \\
\hline $\mathrm{H}$ & 5.9 & 5.8 & 6.0 & 6.3 & 5.8 & 5.6 \\
\hline $\mathrm{N}$ & 0.2 & 0.7 & 0.2 & 0.9 & 0.9 & 1.8 \\
\hline $\mathrm{S}$ & $<0.02$ & 0.1 & $<0.1$ & $<0.1$ & 0.14 & 0.26 \\
\hline $\mathrm{Cl}$ & $<0.1$ & 0.2 & $<0.1$ & 0.1 & 0.26 & 0.46 \\
\hline Fuel composition - trace elements [mg/kg $/$ dry fuel \\
\hline $\mathrm{Si}$ & 10 & 10600 & 9800 & 3600 & 10500 & 27100 \\
\hline $\mathrm{K}$ & 450 & 14000 & 1000 & 7800 & 5200 & 13700 \\
\hline $\mathrm{Na}$ & $<10$ & 90 & 25 & 30 & 600 & 800 \\
\hline $\mathrm{Ca}$ & 800 & 2500 & 1600 & 900 & 8300 & 9400 \\
\hline $\mathrm{Mg}$ & 150 & 800 & 1000 & 1100 & 4200 & 2800 \\
\hline
\end{tabular}

\section{Ash and Slag}

As expected, ash related problems were observed in almost all the experiments carried out with agricultural biomass fuels. Miscanthus and maize proved to be least problematic, followed by horse manure and straw. A higher degree of sintering could be seen in the ash samples from the manure mixed with straw than when wood shavings were used as fuel.

In boilers A1 and A2, big ash lumps were accumulated in the plate area, and the fire was extinguished after a few hours of operation, especially during combustion of straw. At the end of the combustion tests with boiler A3, big and compact ash lumps, with the shape of the burner plate, were formed when straw and Miscanthus were burned. Almost no ash was found in the burner plate at the end of the experiment with maize pellets. Furthermore, almost no slag was found on the grate at the end of the combustion experiments in boiler A4. After the experiments in Boiler S1 and S2 using horse manure mixed with wood-shavings as fuel, sintered material could be found among the ash. During the experiments with horse manure mixed with straw, large sinter cakes or slag were found on the grate after shut-down. 


\section{Operational performance}

The effect of the ash accumulation and slag formation on the operation of the boilers differed depending on the combustion technologies. Some boilers shut down by quenching of the fire after a few hours of operation, while others were able to remove ash and slag from the combustion zone and thus could be operated for a longer period of time.

With the exception of boiler A3, the emissions and the other parameters were measured during a minimum of two to three hours of steady state combustion in all the boilers tested in Austria. In boiler A3, very short periods of steady state combustion, in general less than one hour, were achieved. The use of a smaller plate in boiler A2 increased the space between the walls and the burner plate for the ash to fall down in the screw conveyor. This resulted in considerable improvement in the ash removal capacity of the boiler for all fuels and in particular for maize pellets. Additional changes in the boiler design, e.g., using an even smaller plate with downward bending edges or install a mechanical cleaning system, might be required to strengthen the ash removal ability of the boiler. Boiler A4 was the Austrian boiler with the best performance in removing the ash from the combustion area. The moving grate, which settings could be adapted for different fuel properties, proved to be a good tool for handling fuels with high ash content. Despite the slag tendency of the horse manure fuels (in particular the straw mixture), the ash could slide down towards the screw conveyor without operational problems and both of the Swedish plants could be operated continuously. Table 5 shows the operational performance associated with the boilers capacity to handle high ash content fuels.

Table 5. Operational performance of the tested boilers.

\begin{tabular}{|c|c|c|c|c|c|c|}
\hline Fuels & Boiler A1 & Boiler A2 & Boiler A3 & Boiler A4 & Boiler S1 & Boiler S2 \\
\hline Straw & $\times$ & $\times(\sim) *$ & $\times$ & $\sim$ & - & - \\
\hline Miscanthus & $\sqrt{ }$ & $\times(\times) *$ & $x$ & $\sim$ & - & - \\
\hline Maize whole crop & $\sqrt{ }$ & $\times(\sqrt{ }) *$ & $\sim$ & $\sqrt{ }$ & - & - \\
\hline $\begin{array}{l}\text { Manure + wood } \\
\text { shavings }\end{array}$ & - & - & - & - & $\sqrt{ }$ & $\sqrt{ }$ \\
\hline Manure + straw & - & - & - & - & $\sim$ & - \\
\hline
\end{tabular}

* Symbol inside the brackets corresponds to the performance of boiler A2 after the change.

All the boilers were equipped with automatic fuel feeding, by means of a worm screw. In none of the combustion systems tested in Austria problems related to the feeding were observed. The testes carried out in Sweden were done with fuel fluctuations. In the straw case, the fluctuations were caused by long straws that were rolled up on the feeding screw centre 
forming a plug and for the wood-shaving case, caves and vaults were formed above the fuel feeding screws inside the fuel storage.

\section{Emissions}

The CO, $\mathrm{NO}_{\mathrm{x}}$ and total dust emissions from the combustion tests are shown below. In order to evaluate and compare the different fuels and boiler technologies, the emissio values are juxtaposed with the future limit values in Austria for standardised biomass fuels []. For means of comparison and when available, emission values from the combustion of standard wood pellets, in the boilers tested in Austria, and standard wood chips, in Boiler $\mathrm{S} 1$, are shown.

The CO emissions were in most cases low and below $500 \mathrm{mg} / \mathrm{MJ}$ as shown in Figure 1.

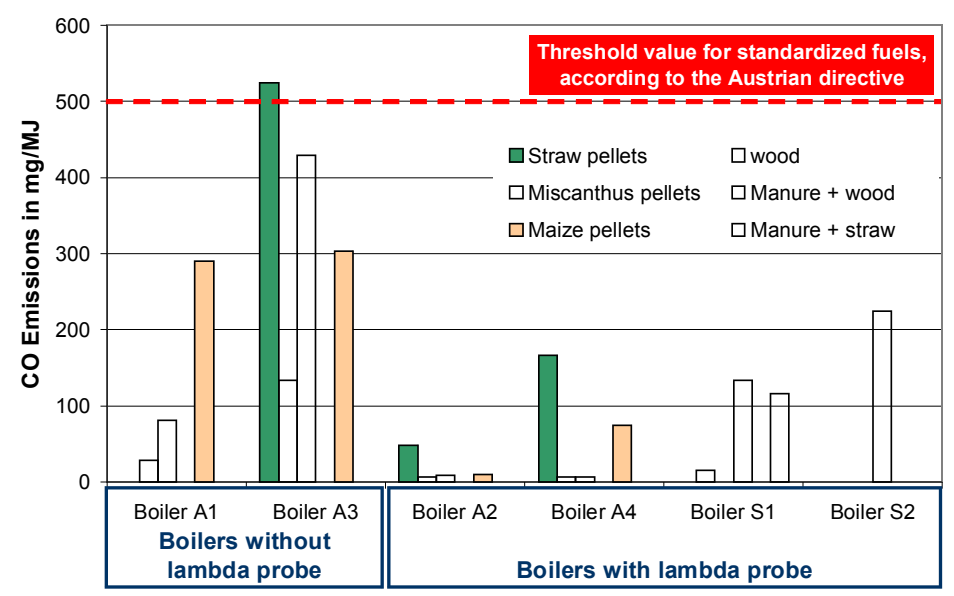

Figure 1. CO emissions from the combustion of wood and agricultural fuels. Threshold value for standardised fuels in Austria according to [].

Comparing the fuels, straw pellets showed the highest $\mathrm{CO}$ emissions in all the boilers, followed by horse manure mixed with straw, horse manure mixed with wood shavings, maize whole crop and Miscanthus. The high CO emissions during combustion of straw pellets are mostly due to disturbances of the burning process caused by, e.g., ash melting or ash lumping. Relatively high $\mathrm{CO}$ emissions were also noticed during combustion of the horse manure mixtures (wood shavings as well as straw). This was in both cases due to the uneven fuel feeding rate causing an unstable combustion process.

When comparing the different boiler technologies tested it can be seen that the $\mathrm{CO}$ emissions are lower in boilers $\mathrm{A} 2, \mathrm{~A} 4$ and $\mathrm{S} 1$ than in boilers $\mathrm{A} 1$ 
and A3. This difference can partially be explained by the different controlling technologies used. The difference can be easily seen in Figure 1. Lambda controlled boilers can operate at a constant excess air ratio independent of the fuel and therefore show a better capacity of adaptation for different fuel qualities than temperature or open loop controlled boilers. The high $\mathrm{CO}$ emissions measured in boiler $\mathrm{A} 3$ are also connected to its design, which leads to too low combustion temperatures and low mixing in the secondary combustion zone. Boilers A2 and A4 as well as boilers S1 and S2, can achieve a good combustion process when operated with agricultural fuels. The other boilers require a more flexible regulation concept when operated with agricultural fuels in order to reduce the $\mathrm{CO}$ emissions.

Figure 2 shows the $\mathrm{NO}_{\mathrm{x}}$ emissions in the different boilers. The emission threshold for wood, $150 \mathrm{mg} / \mathrm{MJ}$, is exceeded by almost all the fuels. Therefore, it is important to make special $\mathrm{NO}_{\mathrm{x}}$ emission limits for non-wood fuels. Moreover, only Miscanthus and straw can fulfil the future limit for non-wood standardised fuels of $300 \mathrm{mg} / \mathrm{MJ}$ in Austria [].

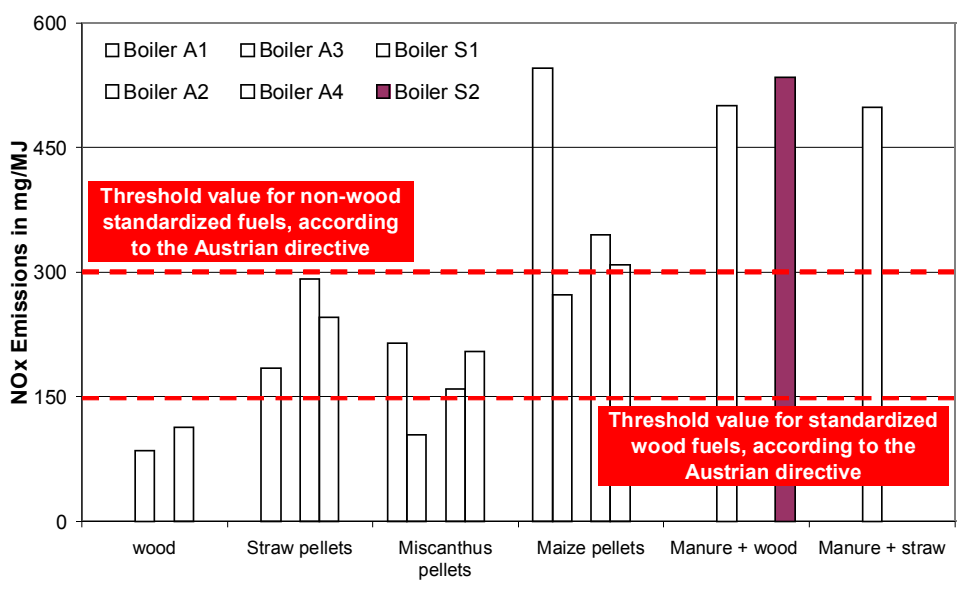

Figure 2. $\mathrm{NO}_{\mathrm{x}}$ emissions from the combustion of wood and agricultural fuels. Threshold value for standardised fuels in Austria according to [].

Figure 3 shows the $\mathrm{NO}_{\mathrm{x}}$ emissions in the different boilers, as well as values from the combustion of wood pellets in boiler A1 as a function of the nitrogen content in the fuels. In all the combustion systems, as expected, an increase of the $\mathrm{NO}_{\mathrm{x}}$ emissions can be seen with the increase of nitrogen content. It can also be noticed that fuels with the same nitrogen content show different $\mathrm{NO}_{\mathrm{x}}$ emissions when burned in different boilers. This means that, apart from the fuel characteristics, the boiler technology also has an important influence on the $\mathrm{NO}_{\mathrm{x}}$ emissions. Boiler $\mathrm{A} 3$ showed the lowest 
$\mathrm{NO}_{\mathrm{x}}$ emission values for all the fuels tested. Despite the high excess air ratio in boiler A3, (varying between 2.5 and 3.5), the mixing of the volatiles with air is poor. Therefore, the primary nitrogen-containing components do not get oxidised but react further with, e.g., hydrocarbon radicals and $\mathrm{CO}$, leading to low $\mathrm{NO}_{\mathrm{x}}$ emissions. The highest $\mathrm{NO}_{\mathrm{x}}$ emissions were shown by boiler A1. The $\mathrm{NO}_{\mathrm{x}}$ emission curves in Figure 3 for boilers $\mathrm{A} 2$ and $\mathrm{A} 4$ follow each other closely.

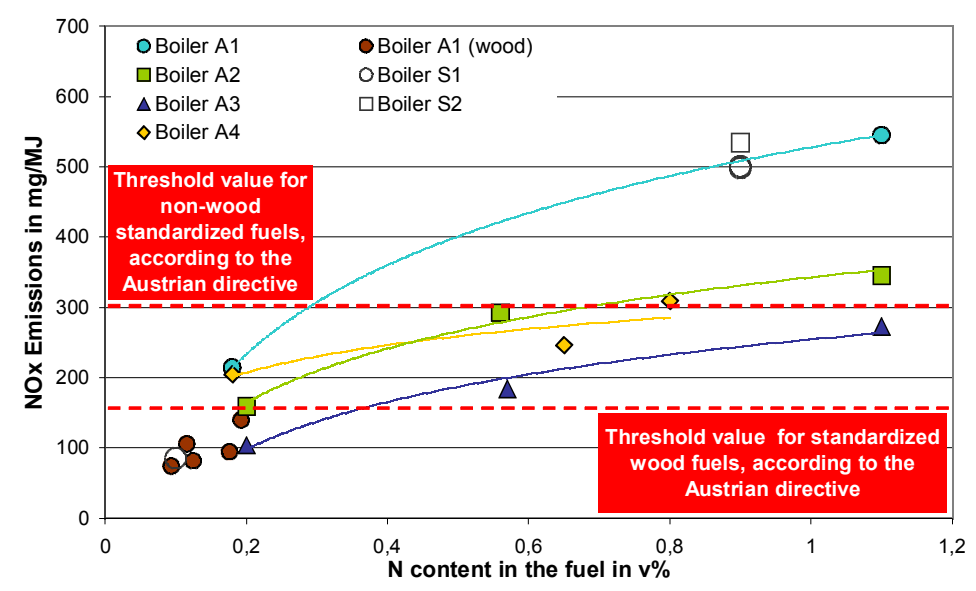

Figure 3. $\mathrm{NO}_{\mathrm{x}}$ emissions from the combustion of wood and agricultural fuels as a function of the Nitrogen content in the fuel. Threshold value for standardised fuels in Austria according to [].

Differences in the combustion chamber design, which influence the residence time and mixing of air and volatiles, as well as the position and proportion of primary and secondary air supply and fuel bed height [], are possible reasons for the differences in $\mathrm{NO}_{\mathrm{x}}$ emissions observed between the boiler technologies. Furthermore, the $\mathrm{NO}_{\mathrm{x}}$ emissions are also affected by the excess air ratio used, i.e., $\mathrm{NO}_{\mathrm{x}}$ emissions increase with increasing lambda values [, ]. Therefore, a further reduction of $\mathrm{NO}_{\mathrm{x}}$ emissions is possible by a combination of improvements of the boiler technology and control strategies that enable a complete combustion of the fuel at low air ratios.

Figure 4 shows the results from the total dust measurements made in Boilers A3, A4 and S2. The dust emissions from boiler A3 and S2 are clearly much higher than from boiler A4. In boiler A3 the operational period with most of the fuels was short (30 minutes to 1 hour) due to problems with slag. Therefore, the dust emissions measured may be higher than that of a steady state full load operation. Extremely high dust emissions where registered for Boiler S2, mainly due to badly optimised control parameters, e.g., primary air supply, and it is doubtful whether these 
emission values are representative. Further measurements at better operating conditions are certainly required to be able to draw any conclusions. Dust emissions from boiler A4, especially when burning Miscanthus, were below the threshold value and comparable to emissions resulting from wood combustion. In general, the emission limit was exceeded when straw and maize were burned. In boilers A3 and S2, since they show relatively high $\mathrm{CO}$ emissions, a decrease in the dust emissions could be accomplished by ensuring a complete combustion.

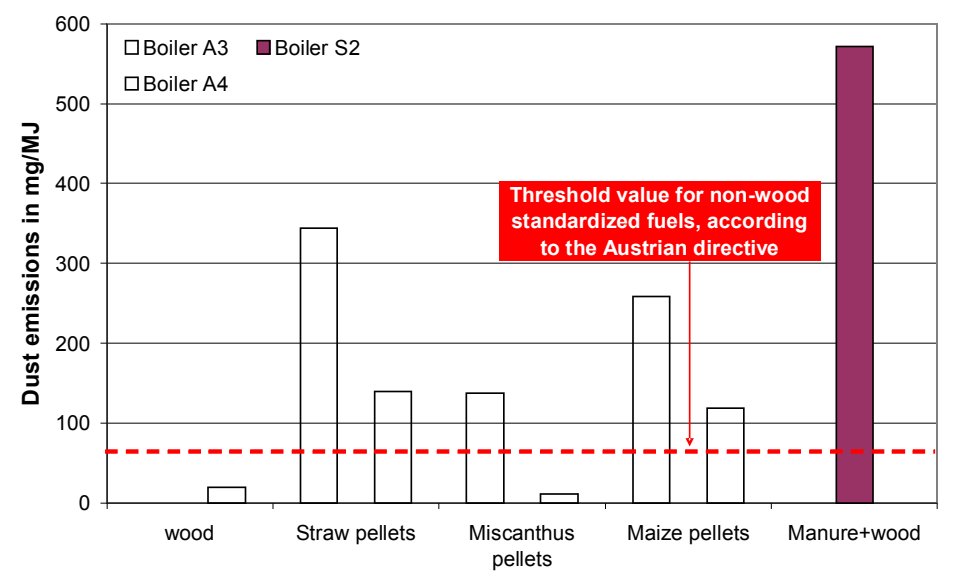

Figure 4. Total dust emissions from the combustion of wood and agricultural fuels in boilers A3, A4 and S2. Threshold value for non-wood standardised fuels in Austria according to [].

\section{CONCLUSIONS}

All the boilers tested required further improvements, in terms of boiler design, combustion technology and/or controlling strategies in order to reach the same level of combustion performance with agricultural fuels as they presently show with wood. The main problems observed were related to ash accumulation on the combustion area and high emissions.

\section{Influence of the type of fuel}

The emissions from Miscanthus combustion were in general below the threshold value for non-wood fuels in Austria [] and in most cases were very close to the values observed for wood when burned in existing pellet boilers. However, a trouble free operation with Miscanthus can only be accomplished in boilers that can handle ash rich fuels. The combustion tests 
with non-wood fuels show that new emission limits need to be implemented for these fuels, in particular regarding emissions of $\mathrm{NO}_{\mathrm{x}}$. Maize and horse manure mixed with bedding material, due to their high nitrogen content, are problematic fuels concerning $\mathrm{NO}_{\mathrm{x}}$ emissions, which were close to or exceeding the threshold value of $300 \mathrm{mg} / \mathrm{MJ}$. Most of the fuels tested showed problems with ash accumulation and slag formation. The Si and K contents were shown to be important indicators of ash sintering degree during combustion. Straw pellets and horse manure mixed with straw, are difficult fuels to burn in boilers optimised for wood due to their high ash content and low ash melting points. In all experiments, ash caking and slag formation was observed in the primary combustion zone, which sometimes also disturbed the burn out of the fuel and led to increased emissions of $\mathrm{CO}$.

\section{Influence of the boiler technology}

The results from the combustion tests have shown that all the boilers require improvements in order to reach the same level of combustion performance with agricultural fuels as they presently show with wood.

The fuels tested can be burned in existing pellet boilers with $\mathrm{CO}$ emissions below the threshold value. However, the type of controlling technology has shown to be an important aspect to achieve even lower emissions. Lambda controlled boilers showed the lowest CO emissions. Steady state combustion processes with different types of fuels can only be assured by using a control technology that can adapt the burning conditions to the different fuel properties. Furthermore, by minimising the $\mathrm{CO}$ emissions and other products of incomplete combustion, the dust emissions can be further reduced. Another important aspect affecting the emissions is the excess air ratio. On the one hand, an increase of the excess air ratio can to a certain extent decrease the $\mathrm{CO}$ emissions considerably and can help to avoid ash accumulation and slag formation by lowering the glow bed temperature. On the other, an increase of excess air ratio can also lead to increased $\mathrm{NO}_{\mathrm{x}}$ emissions and reduced system efficiency. Therefore, the best approach is to improve the combustion chamber design, and air inlets in order to provide sufficient mixing, temperature and residence times at minimum air ratios. The improvement of the controlling technology also plays a crucial rule in order to regulate the excess air ratio, i.e., to minimise the lambda value without compromising a complete combustion process. Staged combustion, or other primary $\mathrm{NO}_{\mathrm{x}}$ reduction measures, should be further investigated and implemented in small-scale combustion systems.

Despite the high degree of sintering shown by some of the fuels tested, the boilers with, e.g., a moving grate, could effectively remove the ash from the primary combustion zone. 
The future use of agricultural biomass fuels will require further development of the existing boiler technologies associated with the combustion chamber design and ash removal system in order to minimise the emissions and to effectively remove the ash from the primary combustion zone.

\section{ACKNOWLEDGEMENTS}

The results presented have been derived in projects carried out within the Kplus-Programme of the Austrian Federal Government. Financial support was received from the Austrian Research Promotion Agency, the Styrian Regional Government, the Styrian Economy Promotion Agency, the Lower Austrian Regional Government and Division of Energy Engineering at Luleå University of Technology, Sweden. The collaborations with Calimax, Fröling, Hargassner KWB, ÖkoFEN and FJ-BLT Wieselburg shall be highly acknowledged as well.

\section{REFERENCES}

1. European Comission, White paper for a community strategy and action plan, COM(97) 599 final, Brussels, 1997.

2. Comission of the European Communities, Biomass action plan, $\operatorname{COM(2005)} 628$ finl, Brussels, 2005.

3. Lundgren J., Pettersson E., Practical, Environmental and economical evaluation of different options for horse manure management Proceedings of the 16th International Congress of Chemical and Process Engineering, Prague, Czech Republic, Aug. 22-25 (CONFERENCE PROCEEDINGS)

4. Werther J., Saenger M., Hartge E.-U., Ogada T., Siagi Z., Combustion of agricultural residues, Progress in Energy and Combustion Science, Vol. 26, pag. 1-27, 2000 (JOURNAL ARTICLE)

5. Miles T. R., Miles Jr T. R., Baxter L. L., Bryers R. W., Jenkins B. M., Oden L. L., Boiler deposits from firing biomass fuels, Biomass \& Bioenergy. Vol 10, N. 2-3, p. 125-138, 1996

(JOURNAL ARTICLE)

6. Obernberger I., Decentralized biomass combustion: state of the art and future development, Biomass \& Bioenergy; vol. 14, N. 1, p. 33-56, 1998

(JOURNAL ARTICLE) 
7. Öhman M., Boman C., Hedman H., Nordin A., Boström D., Slagging tendencies of wood pellet ash during ash combustion in residential pellet burners, Biomass \& Bioenergy; vol. 27, p. 585-596, 2004 (JOURNAL ARTICLE)

8. Bryers R. W., Fireside slagging, fouling and high-temperature corrosion of heat transfer suface due to impurities in steam-raising fuels, Progress in Energy and Combustion Science, Vol. 22, pag. 29-120, 1996

(JOURNAL ARTICLE)

9. Van Loo S., Koppejan J. (Eds), Handbook of biomass combustion and co firing, Prepared by Task 32 of the implementing agreement on bioenergy under the auspices of the International Energy Agency, Twente University Press, Enschede, the Netherlands, 2002

(BOOK)

10. Brunner T., Bärnthler G., Obernberger I., Fine particulate emissions from state-of-theart small-scale Austrian pellet furnaces - chraracterisation, formation and possibilities of reduction, Proceedings of the $2^{\text {nd }}$ World Pellets Conference, Jönköping, Sweden, 2006

(CONFERENCE PROCEEDINGS)

11. Johansson L. S., Tullin C., Leckner B., Sjövall P., Particle emissions from biomass combustion in small combustors, Biomass and Bioenergy, Vol. 25, pag. 435-446, 2003 (JOURNAL ARTICLE)

12. Entwurf einer Vereinbarung zwischen dem Bund und den Ländern gemäß Art. 15a BVG, Inverkehrbringen und Überprüfung von Feuerungsanlagen, 2006 (AUSTRIAN FEDERAL LAW)

13. Lundgren J, Hermansson R, Dahl J. 2004. Experimental studies during heat load fluctuations in a $500 \mathrm{~kW}$ wood-chips fired boiler. Biomass and Bioenergy. 26 (3), pp 255-267

(JOURNAL ARTICLE)

14. Lundgren J, Hermansson R, Dahl J. 2004. Experimental studies of biomass boiler suitable for small district heating networks. Biomass and Bioenergy. 26 (5), pp 443-453 (JOURNAL ARTICLE)

15. Padinger R., Alzueta M. U., ₹mand L. -E., Bilbao R., Ghirelli F., Good J., Hasler P., Hämäläinen J., Heiskanen V.-P., Hofbauer H., Ibáñez J. C., Kilpinen P., Leckner B., Leiser O., Löffler G., Millera A., Nussbaumer T., Oliva M., Oravainen H., Saastamoinen J., Salzmann R., Schaffner H., Spitzer J., Taipale R., Thunman H., Waelti B., Wargadalam V.J., Wartha C., Winter F., Reduction of nitrogen oxide emissions from wood chip grate furnaces (Low-NOx Wood Chip Combustion), Research funded in part by the European Comission in the framework of the Non Nuclear Energy Programme JOULE III.

(FINAL REPORT) 
16. Eskilsson D., Rönnbäck M., Samuelsson J., Tullin C., Optimisation of efficiency and emissions in pellet burners, Biomass and Bioenergy, Vol. 27, pag. 541-546, 2004

(JOURNAL ARTICLE) 